\title{
Public art in Taman Suropati as a medium in creating attractive and lively public space
}

\author{
Yulia Nurliani Lukito $^{1}$ and Rima Aisha Zahra ${ }^{1 *}$ \\ ${ }^{1}$ Departement of Architecture, Faculty of Engineering, Universitas Indonesia
}

\begin{abstract}
The city authority increasingly has interested in cultural sustainability as an aspect of sustainable development and emphasize the design of public urban spaces that host cultural and social interactions. In regard to create sustainability of public space, it is necessary to use both physical and aesthetic elements of the park and art in public realm can be a powerful tool to reach people and play an active role in forming and presenting local identity of cities. In this paper, a research in Taman Suropati, Menteng, Jakarta, is conducted as a case study of how public art in the city park generates interaction between visitors. As a historical landmark of the city, Taman Suropati has its own appeal to the people of Jakarta. The park has provided a good sample of how urban space is activated through public art and community activities. By analyzing the relation between spatial elements and social activities in Taman Suropati, we can learn about the importance of public art to support community interaction and help to create an attractive and lively urban environment. Thus, this paper aims to investigate the role of public art as a tool for enhancing the quality of urban space and making creative, lively urban open spaces to promote a more sustainable urban living and maintain the public realm of cities as an interaction space.
\end{abstract}

\section{Introduction}

The progressive expansion of urban sprawl and the vast development of technology has been a challenge to today's society. In order to respond to the subject, cities have to be prepared with a subsequent strategy in providing a healthy and adequate living environment. Some critiques of the modernist approach to urban planning are the creation of homogenous urban fabric rather than heterogeneous urban texture, space rather than place, segregation rather than integration, and indirect communication rather than direct communication. In other words, modernist approaches have caused placeless urban environments [1].

In the mid-1990s, an alternative urban planning and transportation theory called "smart growth" emerged and popularized across the US [2]. The term itself refers to an approach

Corresponding author: yulianurliani@yahoo.com, aysazara@gmail.com 
of development and conservation strategies, concerning to create a healthy and natural environment that supports strong economic growth, attractive communities, and diverse societies [3]. The Smart Growth Network has developed a set of principles that includes fostering attractive communities with a strong sense of place, preserving open space, strengthening development towards existing communities, as well as encouraging community and stakeholder collaboration in city development.

As part of thinking method in city planning, the availability of green public space and community involvement become a popular topic in urban discussions [4]. Open public space does not only supply the ecological support through greeneries but also allows people to actually use and interact in public space. The example of this specific feature can easily be taken from public parks that have the power to provide a refreshing environment and a choice of venue for community activities.

There are many variables that incur people's perception and attraction to public parks. In the environmental aspect, the most visible factors are spatial configurations, facilities, and aesthetic or landscape features $[5,6]$. In addition, a park has several foundational elements [7]:

- site occupying, how the park is formed on the site, situated and suited to its surrounding (merging, separating);

- game establishment, what special significance that is brought by the park (shape composition, narrative);

- $\quad$ space shaping, how the land supports any element that is defining vertical boundaries of the garden (modification, leveling);

- $\quad$ climate creation, how a certain climate is arranged in a park (shading, cooling);

- life lending, how the park is born and lived as a place (maintaining, occupying).

Those elements may help us to understand the spatial configuration of the park and social occurrence or visitors' experience. Spatial or physically configuration of the park affect people's attraction and their behavior, and thus, the configuration indicates the success of public space [8].

Art in the city - ranging from fine art to street furniture - can be a perfect integration built environment and the continuity of the city culture. This public art constitutes space forms that reflect the overall emotional implication of environment and artistic taste by combining nature, culture, space organization and social interaction. Public art, such as sculpture, become an aesthetic feature and help to facilitate a conversation that comes from the community. The term 'public art' is generally referred to an artwork that located externally - ranging from monument to graffiti painted on the wall by the public - and frequently used as a term covering any artwork that not displayed in art galleries [9]. The term 'public art' in this paper also refers to the artworks with the participation of community members that are located in free accessed spaces.

It is now widely recognized that art in public realm can be a powerful tool to reach people, present and represent cultural, social and local identities and even play an active role in forming and changing cultural meanings and identity of cities. Art in the public realm of cities can be a vehicle in the formation of urban spaces. Urban spaces that have public art and accommodate art activities may have some potentials to attract and host social, cultural, educational events. City authorities such as in Jakarta show exceptional attention to city parks at least since the launch of RPTRA (Children Friendly Integrated Public Space) program in 2015 [10].

This paper explores the sustainability of public space in the city and public art in the way public art plays a role in making urban life attractive and livable. As a case study is Taman Suropati, Menteng, Jakarta, a historical landmark of Jakarta that is also as a successful public space that attracts many visitors. The park has several artworks and 
becomes a venue for art communities, informal music class, and public discussion. It is then possible to observe and analyze relations between aesthetic features in the park with community activities. Thus, this paper aims to investigate the role of public art as a media for enhancing the quality of urban space and making creative, lively urban open spaces to promote a more sustainable urban living and maintain the public realm of cities as an interaction space.

\section{Methodology}

This research mainly uses literature research and field observation. First, the literature research is conducted to discuss the concept of public space, the importance of public art in creating livable and sustainable urban space. The research mainly uses qualitative methods to relate data from kinds of literature, interviews, and observation to support the relationship between public art and community activities.

Field observation becomes the important way of collecting firsthand information for the analysis of the case study. Taman Suropati in Menteng, Jakarta, is chosen as a case study since the park has some artworks displayed as Association of South East Asian Nations or ASEAN's Monument of Peace and some art communities even conduct plays, classes, and discussions in the park. Field observation also consists of data collection from a series of in-depth interviews that will be carried out with mainly local artists and visitors of the park to reveal the significance of public part in promoting social interaction and livable public space. Then, the research will examine and analyze the existing conditions of the park including spatial configuration, facilities, and aesthetical features and social participation happened at the park. The last part is crucial to give us a clear perspective on how elements of an open public space, which is related to public art, may generate a particular narrative or a sense of the place that attracts visitors.

\section{Findings and discussions}

Taman Suropati is located in Menteng, Central Jakarta. The area itself was first designed and built in the early 1920s as an expansion of the city of Batavia, the center of Dutch colonial administration. With the influence and idea of garden city movement, Menteng was first intended to be an elite residential for bourgeois society in the Dutch colonial society. To support the garden city concept, Menteng had houses with gardens, open and green spaces as well as trees and big boulevards that combined the best of town and countryside. In the original design designed by Pieter Adrian Jacobus Moojen, Menteng area had a radial street pattern and residential blocks with a big park as the center. The big park was never built but in its location was later developed into a public park, previously called Burgemeester Bisschopplein and nowadays is known as Taman Suropati [11]. 


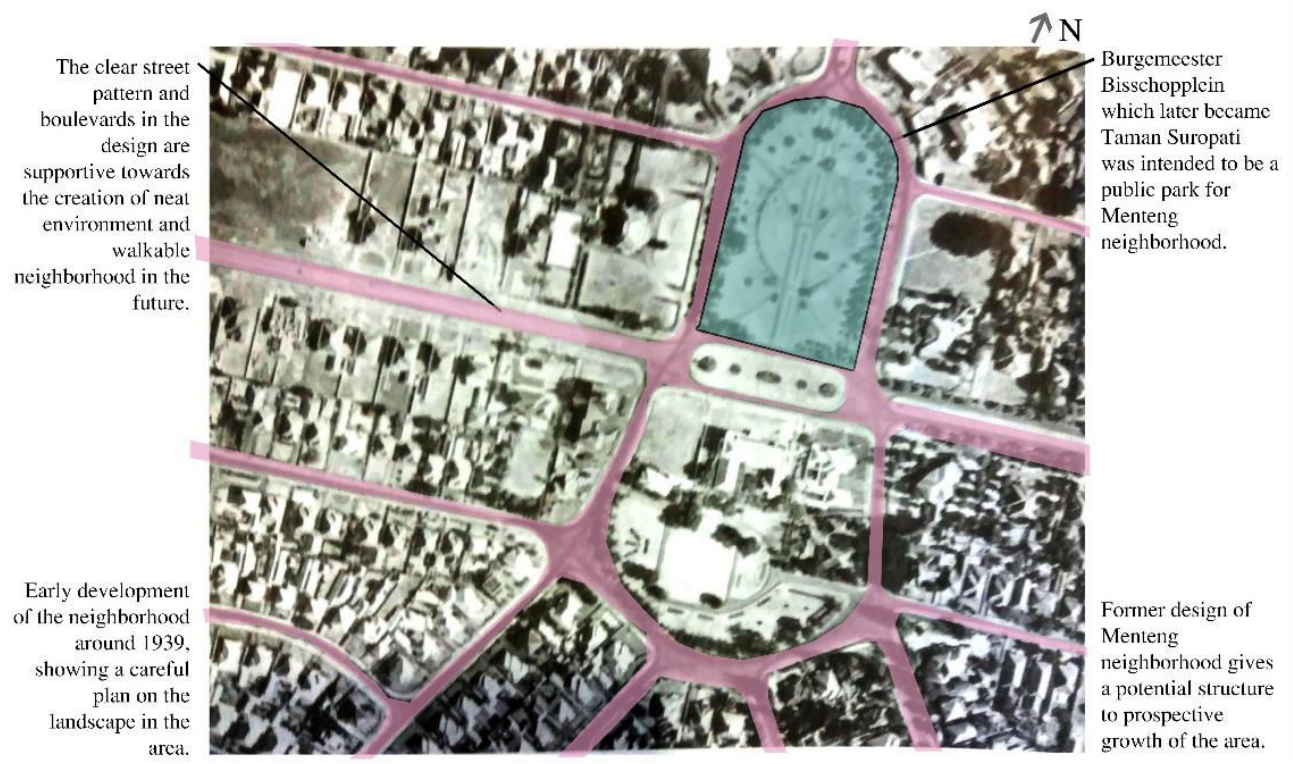

Fig. 1. Aerial view of early development in Menteng. Source: Authors' illustration.

Menteng area is now surrounded by important business, governmental and residential districts, reflecting the development of Jakarta from a colonial city to a metropolitan. Increasing land values in the center of Jakarta give pressures on the edges of Menteng to convert to non-residential uses such as shops, offices, and restaurants. Because Menteng has distinctive architecture and important history, a 1975 gubernatorial decree declared Menteng a cultural heritage area. However, problem-related to the conservation of Menteng residential area still occurs and some residences sell their house due to the rising land taxes.

By this circumstance and adding the fact that it was designed as a garden city, Menteng neighborhood has the opportunity to apply and make use of certain aspects it already has to support and sustain smart growth principles. For instance, from time to time the sidewalk around Menteng, unlike many other parts in Jakarta, was properly maintained for pedestrians.

Menteng area actually has the advantage of good infrastructure, strategic location and the long history of the city. Authorities want to improve the livability of this urban area by ensuring access, good transportation, parks and public spaces in the area. Lately, Taman Suropati becomes a place of community where they are free to express their creative interests. Therefore, the park has some potential attribute to generate social interaction. 


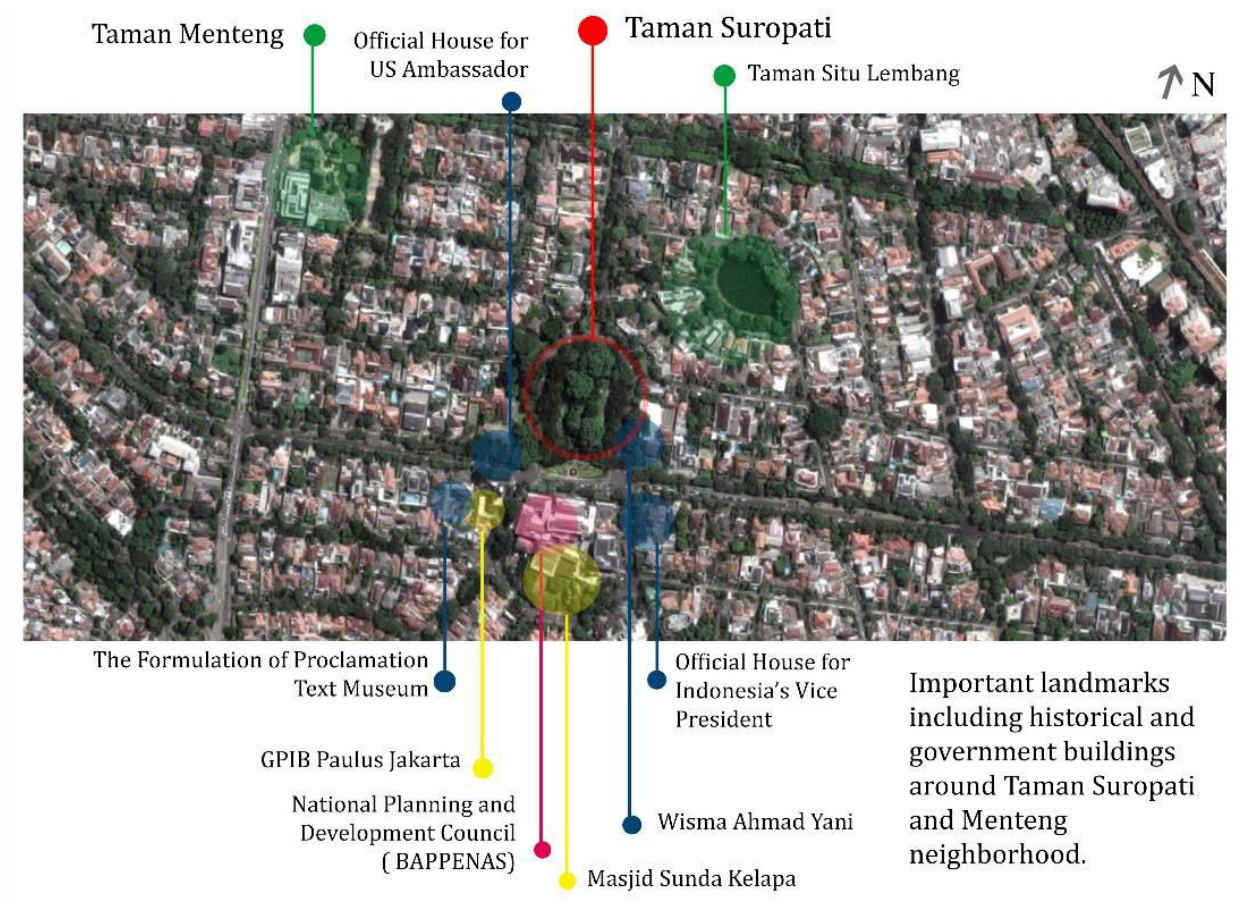

Fig. 2. Landmarks around Taman Suropati. Source: Authors' illustration.

As one of a few public parks located in Menteng, Taman Suropati is open to the public and connected to some public transportation. The park itself has a circular form, an island bordered by streets and a meeting point of three main streets Teuku Umar Street, Diponegoro Street, and Imam Bonjol Street. The circular form was the result of the architect's intention to avoid traffic jam around the parks. Buildings around the park are mostly luxurious houses with high fences, giving the impression of the upscale Menteng residential area. From outside the park, people can see some artworks that are put in disperse across Taman Suropati. In 1984, the Association of South East Asia Nations (ASEAN) placed six sculptures to commemorate friendship and peace among its members, replacing animal statues that were formerly placed in the park. Those six sculptures were created by six artists from six pioneer countries of ASEAN, united and legalized under the name ASEAN's Monument of Peace [12].

The term public art refers to works of art in any media that has been staged in the public domain and accessible to all. In Taman Suropati, people can enjoy the scenery that has plenty of shady trees as well as sculptures. People also often visit Taman Suropati to hang out, exercise or join one of the art classes. Presentation of those works of art by visual artists, musicians, and performers in public Taman Suropati brings cultural expression to the urban landscape while introducing the public to art practices. 


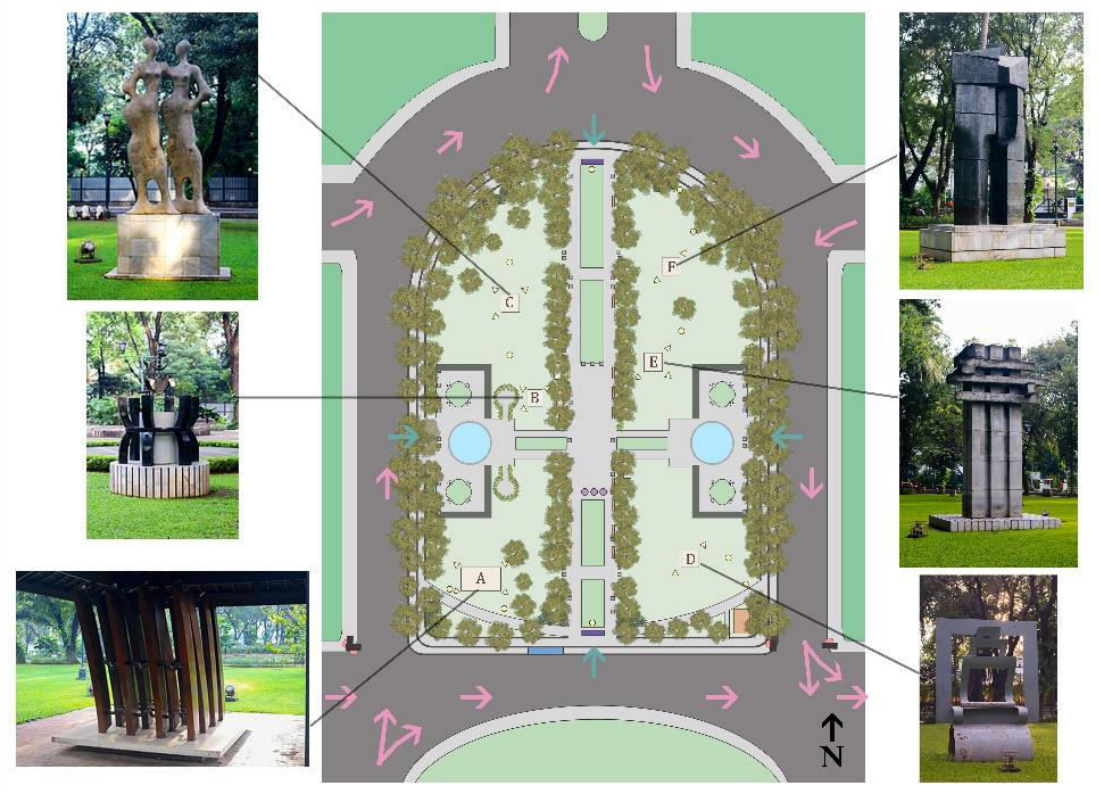

Fig. 3. Access, entrances, and ASEAN artworks in Taman Suropati. Source: Authors' illustration.

Around the year 1997, a group of street musician, initiated by Agustinus Hesti Dwiharso, started to hold music rehearsals in Taman Suropati [13]. Previously, the park was occupied by paintings sellers who sold their works along the side of the park to people passing by, but later on, local authorities ruled out the sellers. For sometimes, the park was associated with negative youth activities such as teenage crime and delinquency. Following the street musicians, other artists also come to Taman Suropati and used the park for their activities. They have discussions and use the park as the place for their art class and creative activities. Later on, an orchestra group with the name Taman Suropati Chamber was formed in 2007. Then, some other street artists joined the group and expanded into an even larger art community with the name of Kota Seni Taman Suropati. This art group consisted of street artists with various expertise besides orchestral music, such as sketch drawing, painting, theatre, photography, and crafts.

Nowadays, people can also find some other communal activities taking place around the park beside those activities held by the art community. On weekends, there is free yoga, tai chi, and aerobics classes. Taman Suropati is a famous place for listening to music performances from local musicians of various genre. Some visitors such as $r$ bike community and school students use spots around the park's plaza as their meeting place. However, it is the art community that already regularly open violin and other art classes on weekends that has given a distinctive quality to the park. The sound of instruments gives a certain kind of atmosphere that become a back sound for the park and attracts people. Along with the existing public art, the art community has given unique and artistic quality through the sound of violin strings and art activities that become a part of aesthetic features in the park. 

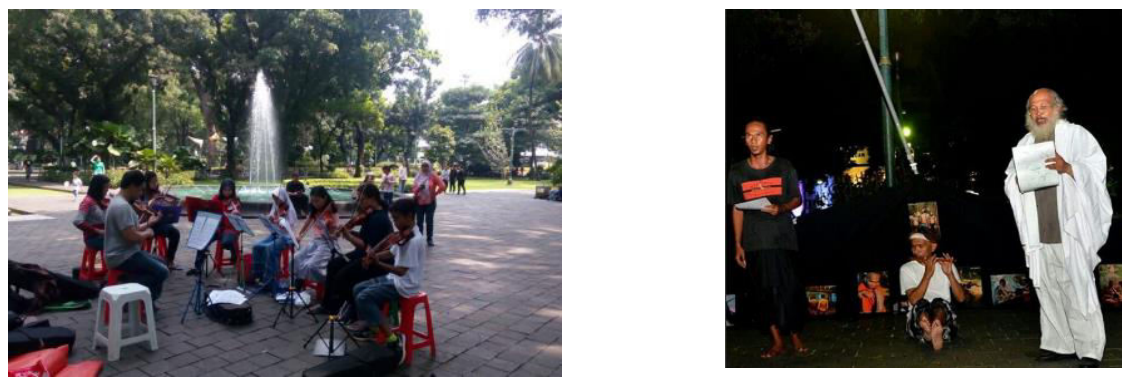

Fig. 4. Violin class and art performance in Taman Suropati. Source : majalahbobo.org, RSS Suropati archive.

The artworks become a part of the physical configuration of the park that also attracts and people and even create boundaries and mark for their activities. The sculptures may be treated as art displays and their presence may be considered as a background but their existence has created a livable space of interaction. Both the artworks and the art community support the same narrative of the place - as public space loaded with artistic meaning in its history and development. Even though they are not necessarily connected to each other, in various degrees, the artworks and community activities contribute in shaping a sense of artistic value in Taman Suropati.
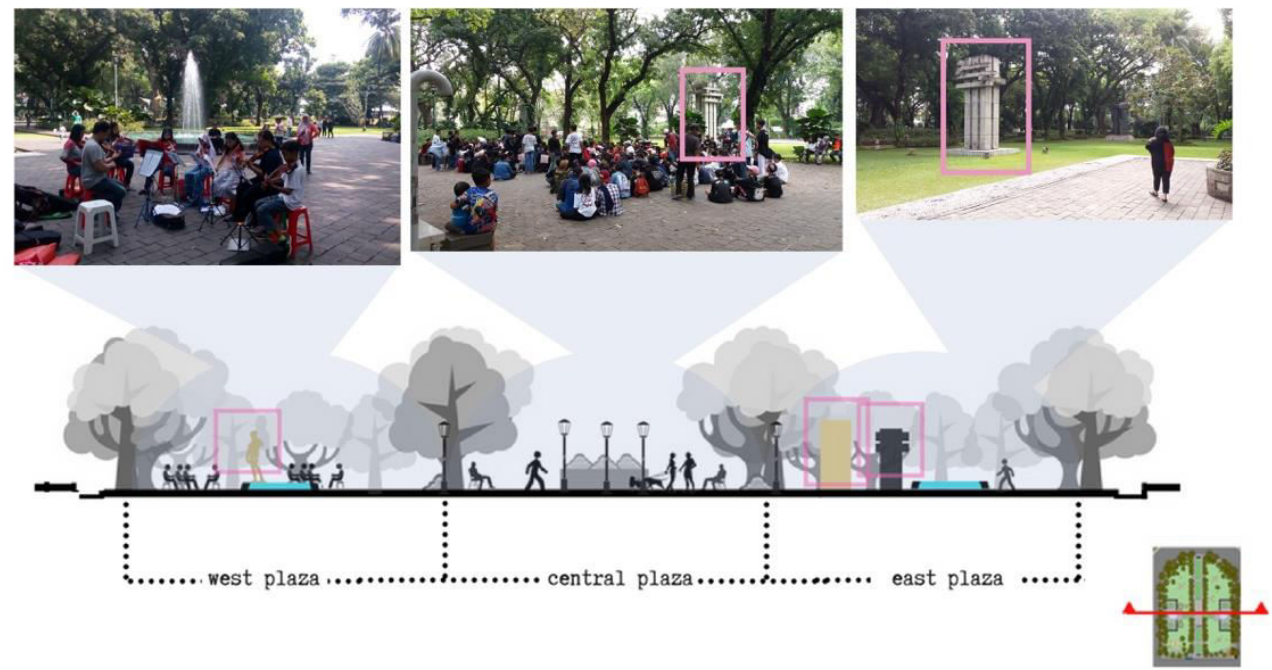

Fig. 5. Situations of West, Central, and East Plazas in Taman Suropati. Source: Authors' illustration.

To be able to effectively function as a point of attraction, the visibility of the artworks is vital. In Taman Suropati, people have good access to the park and good visibility to the artworks. Taman Suropati has some entrances accessed from four different directions. Although people have to park their vehicle quite away from the park, they usually walk to enter the park. There are three plazas at the park that can accommodate different functions happen simultaneously. When a group of people uses the central plaza, they can easily look at sculptures located in the middle of the park, thus, those sculptures work as a marker to the place and create a certain kind of atmosphere to the middle plaza. 
There is a good visual connection from visitors of the park to the public arts. Since the position of ASEAN sculptures are not central but spread in the park, those sculptures do not look dominant. Community's activities are influenced both directly or indirectly by the presence of the public art by giving a significant artistic value to the park and also become a boundary for social interaction happened at the plazas. As an example, people at the park can hear the sound of violins coming from musicians and their students who have a class at the west plaza. The unique violin sounds create a distinctive atmosphere and identity for the park together with the natural sounds of water from the fountain, birds chirping, and people chattering.

People who use the park mostly come from outside the Menteng area and from various background of society. Communities who occupy the park contribute to branding the park suitable for art activities. The artworks improve the attractiveness of the area and celebrate the history and the uniqueness of local activities. This means that community activities reflect a lively social environment and art becomes the medium of public interaction. In other words, public art in Taman Suropati helps to improve the quality of urban life.

\section{Conclusion}

The availability of open public space and the use of public space to support community become important issues in urban discussions. Open public space not only should supply the ecological support but also allows people to interact in the place. Public parks like Taman Suropati provide a refreshing environment and a place for community activities and the activation and optimization of park usage can be done through the presence of public art.

From Taman Suropati, we can learn that public art, together with the narrative of the park as part the development of the city, make the park attractive and support the livability of the park. The artworks improve the attractiveness of the area and celebrate the uniqueness of the place, and later they attract people to come and hold group activities. The artworks, together with the art community support the same narrative of the place - as public space loaded with artistic meaning in its history and development - as well as branding the park with art activities. The emersion of artworks and art community in the park may not be intentionally created as a set of supporting elements to the narrative, but they are proven as compatible aspects that construct an aesthetic quality of the place.

In enhancing the sustainability of urban space, using public art can be helpful to create an attractive public space. More than just aesthetical medium, public art helps to create a positive engagement of people to the place and the community. In this way, public art can be utilized to enhance the quality of public space.

\section{Acknowledgments}

The research of this paper is conducted with the support of PITTA grand from DPRM Universitas Indonesia.

\section{References}

1. S.M. Natrasony, D Alexander, The rise of modernism and the decline of place: the case of Surrey City Centre Canada, Planning Perspectives 20, 4, 413-433 (2005)

2. R.W. Burchell, D. Litoskin, C. Galley, Smart Growth: More Than a Ghost of Urban Policy Past, Less Than a Bold New Horizon. Housing Policy Debate 11, 4, 821-829 (2000) 
3. Maryland Department of Planning. What is Smart Growth? Retrieved July 2018, from Smart Growth Online: https://smartgrowth.org/what-is-smart-growth/ (2015)

4. T. Baycan-Levent, P. Nijkamp, R. Vreeker, A Multi-Criteria Evaluation of Green Spaces in European Cities. European Urban and Regional Studies 16, 2, 193-213, (2009)

5. E. Leeuwen, P Nijkamp, T. Vaz, The multi-functional use of urban green space.

Retrieved July 27, 2018, from

https://www.researchgate.net/publication/46433689 The multifunctional_use of urban_green_space (2009)

6. Y. Chen, T. Liu, X. Xie, B. Maruši'c, What Attracts People to Visit Community Open Spaces? A Case Study of the Overseas Chinese Town Community in Shenzhen, China. International Journal of Environmental Research and Public Health. 13, 7, (2016)

7. C. Moore, Jr., W. J. Mitchell, The Poetics of Gardens (1993)

8. A. Madanipour, Why are the design and development of public spaces significant for cities? Environ. Plan. B Plan. Des., 26, 6, 879-891 (1999)

9. D. Hunting, Public art policy: Examining an emerging discipline, Perspectives in Public Affairs, 2 (2005)

10. L. Huda, Ahok to Build 213 RPTRA This Year. Retrieved from tempo.com https://en.tempo.co/read/news/2016/03/08/055751786/Ahok-to-Build-213-RPTRAThis-Year (2016)

11. A. Heuken, Menteng "Kota Taman" Pertama di Indonesia (2001)

12. A. Mardiani, Rekreasi dan Beraksi di Taman Suropati. Retrieved from Historia: https://historia.id/kota/articles/rekreasi-dan-beraksi-di-taman-suropati-DB4Kx (2015)

13. C. Lubis, Evolusi Kota Taman. Retrieved 1 Mei 2018, from Metronews.com: http://telusur.metrotvnews.com/news-telusur/9K57Og1b-evolusi-kota-taman (2017) 